\title{
Should CBA's include a correction for the marginal excess burden of taxation?
}

Frits Bos

Thomas van der Pol

Gerbert Romijn 



\title{
Should CBA's include a correction for the marginal excess burden of taxation? ${ }^{1}$
}

\section{Frits Bos* ${ }^{\star 1}$, Thomas van der Pol ${ }^{2}$ and Gerbert Romijn ${ }^{1}$}

*Corresponding author, f.bos@cpb.nl, 31-625063936.

${ }^{1}$ CPB Netherlands Bureau for Economic Policy Analysis

2 Global Climate Forum Germany

\begin{abstract}
According to economic theory, taxation drives a wedge between private and public benefits, which distorts labour supply, consumption and investment and leads to loss of welfare. One would therefore expect that in cost-benefit analysis (CBA) of public expenditure a correction is made for the costs of taxation, i.e. for the marginal excess burden of taxation (MEB).

However, looking at CBA practice all over the world, textbooks on CBA and various specific CBA guidelines no consensus exists about such a correction. This paper provides for the first time an overview of the theoretical, empirical and practical arguments in favor or against a MEB correction. It argues that in general the best approach for CBA's is to assume that the MEB is broadly counterbalanced by the benefits of redistribution of these taxes. This assumption is consistent with the preferences for equality in a country's current tax system and is a simple, pragmatic and politically neutral assumption. This assumption does not imply that the tax system is optimal or that CBA's should be distributionally weighted. As a consequence, the preferred approach is to assume in general that the marginal cost of public funds is equal to one and then no correction is needed in CBAs for the MEB. Choosing an alternative source of financing, i.e. other than general tax revenues, should be regarded as a separate policy measure that should be analysed separately in a CBA.
\end{abstract}

Key-words: Cost-benefit analysis, Marginal excess burden of taxation, Marginal cost of public funds, Hicks-Kaldor criterion, Distributionally weighted CBA

JEL-codes: $D 61, H 20, H 43$

\footnotetext{
${ }^{1}$ An earlier version of this paper was presented at the $9^{\text {th }}$ Conference of the Society for Benefit-Cost Analysis, March 15-17, 2017, Washington DC. The authors would like to thank Massimo Florio, Clemens Kool, Judy Temple, Jack Wells and the members of the Dutch CBA-working group on the MEB, in particular the four professors in economics Casper van Ewijk, Bas Jacobs, Carl Koopmans en Erik Schokkaert, for their comments and text suggestions; this paper is an extended and modified version of part of the report by this Dutch working group..
} 


\section{Introduction}

A basic insight from economic theory is that taxation drives a wedge between private and public benefits. This distorts labour supply, consumption and investment and leads to loss of welfare. One would therefore expect that in cost-benefit analysis of public expenditure a correction is made for the costs of taxation, i.e. for the marginal excess burden of taxation (MEB, see e.g. Pigou, 1928 and references in section 2).

In line with this insight, Boardman et al. (2006) recommend a correction for the MEB. For the USA, it is suggested to use $40 \%$ for federal projects (assuming the income tax is the marginal source of finance) and $17 \%$ for locally financed projects (local real estate tax is the marginal source of finance). The federal CBA guidelines in the USA (OMB, 1992, Circular A94) recommend a MEB correction of 25\%. A recent article on preschool programs (Heckman et al., 2010), uses three different corrections for the MEB to calculate their social rate of return: $0 \%, 50 \%$ and $100 \%$.

However, in CBA practice all over the world, it is most common not to make a correction. An overview of CBA's on transport infrastructure in Europe (Bickel et al., 2006) shows that in only four countries a correction for the MEB is made. For example, in Denmark and Slovenia, the correction is $20 \%$ and in Sweden $30 \%$. In the other countries no correction is made. In the USA, despite the federal CBA guidelines and the textbook by Boardman et al., no correction is made for CBA's on transport infrastructure. ${ }^{2}$

The reasons why no correction should be made are often not spelled out or only very briefly discussed. In many CBA guidelines, like those by the World Bank (1994), the Asian Development Bank (2013), the OECD (2006) and the USA Benefit-Cost Center (Zerbe et al, 2010), the issue of the MEB is not even mentioned. In the EU CBA guidelines for investment in infrastructure financed by the cohesion funds (European Commission, 2014), the issue is hardly discussed and no correction is recommended unless the national CBA guidelines prescribe this. In the European overview on CBA's on transport infrastructure, in particular the uncertainty of the estimate of MEB is put forward as a reason not to make a correction. In some economic literature, it is argued that no correction for MEB is needed in case of optimal taxation (e.g. Jacobs et al., 2009 and Jacobs, 2016) or when a public good is financed distributionally neutral (e.g. Kaplow, 1996 and 2004). However, they do not discuss what to do in CBA practice when the theoretical conditions of their model may not apply. In the classic CBA textbook Mishan and Quah (2007, p. 240), corrections for the MEB are regarded as "a common error in the many textbooks on the subject". ${ }^{3}$ It stresses the uncertainty of the MEB estimates, but does not discuss the theoretical perspectives of optimal taxation and distributionally neutral financing.

\footnotetext{
${ }^{2}$ Source: Jack Wells, former senior economist at the US Department of Transportation.

${ }^{3}$ In the federal CBA guidelines in the USA (OMB Circular A4), reference is made to this textbook for further guidance and background on CBA. But the opinion of MEB in this textbook clearly contradicts the federal CBA recommendation to make a MEB correction of $25 \%$.
} 
In the Netherlands, CBA and the correction for MEB has been subject to intense debate among leading economists for some time. ${ }^{4}$ The recently revised Dutch CBA guidelines (Romijn and Renes, 2013) only state that the issue still has to be clarified. Therefore, the Dutch government has asked a special CBA-Working group 5 to advice on this issue. The advice should be relevant for all policy areas, so not only for transport infrastructure, but also for health care, energy, environmental policies, social security, labour market policy and tax policy. Broadly in line with the Working group's report ${ }^{6}$, this paper investigates the theoretical, empirical and practical arguments in favor or against a MEB correction. ${ }^{7}$

This paper contributes in various ways to the existing literature. Firstly, no systematic overview of these arguments exists. Textbooks and guidelines on CBA ignore the issue or provide a limited and unbalanced overview of these arguments, while more academic papers ignore the link with CBA practice. Secondly, several new arguments are put forward, in particular about the plausibility of the theoretical assumptions of optimal taxation and distributionally neutral taxation. Thirdly, the link between CBA practice and a broad concept of welfare is discussed. This reveals that from a welfare point of view corrections are not only needed for the MEB, but also for distributional benefits of these taxes and for the distributional benefits of the policy measure itself. Proposals for corrections for the MEB should therefore also be discussed in view of how to take account of these distributional benefits.

Section 2 starts with the perspective from economic theory. This includes not only a discussion of the costs of taxation, but also of the distributional benefits of taxation and their link to the practice of CBA and a broad concept of welfare. To this end, a general framework for CBA is presented in which the costs of taxation and the benefits of redistribution are linked to the other elements that are commonly identified in a CBA. The framework consists of two parts. The first part starts from the current worldwide CBA practice and covers the costs and benefits without any correction for MEB. The balancing item 'net benefits' aggregates costs and benefits irrespective of who gains and who loses and thus follows the principle of 1 euro is 1 euro. This principle is also known as the Hicks-Kaldor criterion. The second part of the framework shows the corrections for MEB and distributional benefits of taxation and distributional benefits of the policy measure, which are needed to arrive at a broad concept of welfare.

Starting from this framework, section 3 investigates whether the marginal distributional benefits of taxation are equal to the marginal distortionary effects of taxation? If this is true, then no correction for the MEB is needed and the marginal cost of public funds is equal to 1 .

\footnotetext{
${ }^{4}$ See De Nooij and Koopmans (2004), Jacobs and de Mooij (2009) and Koopmans and De Nooij (2009).

${ }^{5}$ The working group consisted of four professors in economics (van Ewijk, Jacobs, Koopmans and Schokkaert) and representatives of various Ministries and representatives of three national research institutes: PBL Environmental Planning Agency, CPB Netherlands Bureau of Economic Policy Analysis and KiM Netherlands Institute for Transport Policy Analysis. One professor served as chairman, the Ministry of Finance and CPB provided the secretaries and CPB provided also research support. An overview on cost-benefit analysis in the Netherlands is provided by Bos and Zwaneveld (2017). On the role of cost-benefit analysis in the Dutch fiscal framework, see Bos (2008 and Bos and Teulings (2012 and 2013).

${ }^{6}$ See Werkgroep Kosten van belastingheffing en MKBA's (2017).

${ }^{7}$ It is also possible to correct indirectly for the MEB, e.g. by employing a benefit/cost criterion substantially higher than one, or to incorporate it in the discount rate, as taxation of capital makes it more expensive to transfer money from one period to another (see Harberger, 2007, Burgess and Zerbe, 2011 and Burgess, 2013).
} 
This issue will be investigated for financing via the general tax revenues and for other types of financing, e.g. specific types of tax or social security contributions, local taxes and toll fees.

How to account in CBA practice for distributional benefits of the policy measure is the topic of section 4. From a welfare perspective, such distributional benefits are important and should be included in the net CBA balance by distributional weighting and not by applying the Hicks-Kaldor criterion, which is most commonly applied in CBA practice all over the world.

Conclusions are drawn in section 5. 


\title{
2 Costs of taxation, welfare and cost-benefit analysis
}

\author{
Marginal cost of public funds and distortionary taxes \\ The marginal cost of public funds $(\mathrm{MCPF})^{8}$ can be defined as the ratio of the social value of an \\ extra public euro (i.e. a euro used for a public policy measure) and the social value of an \\ extra private euro (i.e. a euro used for private purposes). Taxation drives a wedge between \\ social and private benefits from economic activities, like work, entrepreneurship and \\ schooling. This wedge induces substitution towards less taxed or untaxed activities (e.g. \\ leisure) and this causes a loss of welfare. As a consequence, in order to finance one euro of \\ public expenditure, more than one euro needs to be extracted from the private sector. It is \\ therefore commonly argued that the MCPF is larger than one due to the distortionary costs of \\ taxation ${ }^{9}$.
}

In economic theory, Pigou (1920) ${ }^{10}$ was the first to advocate that in comparing the costs and benefits of a public good also these distortionary costs of taxation should be taken into account. In formal economic theory, this idea was taken up by Stiglitz and Dasgupta (1971), Diamond and Mirrlees (1971) and Atkinson and Stern (1974). They modified Samuelson's rule on the optimal provision of public goods (Samuelson, 1954) ${ }^{11}$ to also take tax distortions into account. In the case that public goods are financed by distortionary taxes, this adds to the cost of providing the public goods. This reduces the optimal provision of public goods ${ }^{12}$ and causes the optimal size of the government to be smaller.

The size of the distortion is different for different taxes. A number of well-known cases are distinguished in economic theory. For example, lump sum taxes do not distort, neither do taxes on goods with inelastic supply or inelastic demand. On the other hand, taxes on wages and investment income distort the supply of labour and decisions on personal saving and investment. Some taxes may even reduce distortion by internalizing negative externalities, e.g. a tax on polluting activities.

\footnotetext{
${ }^{8}$ This definition is in line with Diamond (1975). It definition stresses that the public value of an extra private euro differs from the private value of an extra private euro by amount of the income effects of taxation. This definition of MCPF resolves major problems in the economic literature (see Jacobs, 2018). First, MCPF is 1 if lump-sum taxes are optimized. Secondly, a direct correspondence is obtained between MCPF and MEB if distributional benefits are absent. In particular, the MCPF of distortionary tax equals the inverse of one minus the MEB. Finally, MCPF measures become insensitive to the normalization of the tax code.

${ }^{9}$ This includes also the extra costs of tax collection and the extra costs in order to limit tax evasion and tax avoidance. In average terms, these costs will not be negligible. But in marginal terms they will be generally small, as these costs mostly consist of fixed costs irrespective of the level of the tax rates (see Jacobs, 2015).

10 "Where there is indirect damage, it ought to be added to the direct loss of satisfaction involved in the withdrawal of the marginal unit of resources by taxation, before this is balanced against the satisfaction yielded by the marginal expenditure. It follows that, in general, expenditure ought not to be carried so far as to make the real yield of the last unit of resources expended by the government equal to the real yield of the last unit left in the hands of the representative citizen" (Pigou, 1928; 1947, p. 34)

${ }^{11}$ According to Samuelson's rule a public good should be provided as long as the overall benefits to consumers from that good in terms of their aggregate willingness to pay are at least as great as the cost of producing it.

${ }_{12}$ Provided that the public good is complementary with taxed private goods.
} 


\section{Distributional benefits of taxation}

Taxes are needed to finance public expenditure. However, if taxes on wages and investment income are distortionary, this raises the question why, nonetheless, such taxes are in practice preferred to less distortionary taxes. The answer lies in the distributional benefits of such taxes. Taxes with minor distortionary effects ${ }^{13}$, like fixed levies per inhabitant ('poll tax'), are in particular a heavy burden for households with low income. In order to avoid or limit this, most major taxes are related to income, wealth or consumption: these are more distortionary, but reduce inequality.

The distributional benefits of income tax were already stressed by Pigou (1920; 1952, p. 89):

"The old law of diminishing [marginal] utility ... leads securely to the proposition: any cause which increases the absolute share of real income in the hands of the poor, provided that it does not lead to a contraction in the size of the national dividend from any point of view, will, in general increase economic welfare."

This quote also indicates that Pigou was aware that distributional benefits may be accommodated by efficiency losses, i.e. a contraction in the size of the "national dividend". This trade-off between equity and efficiency is the theme in Okun (1975). His central rule is "Promote equality up to the point where the added benefits of more equality are just matched by the added costs of greater inefficiency." He argues that a Leaky-Bucket experiment can test attitudes towards this trade-off. To carry money from the rich to the poor is like transporting water with a leaking bucket as some money will inevitably disappear. How much leakage will you accept and still support to levy an added tax to the top $5 \%$ of income distribution to benefit the bottom $20 \%$ of income distribution? According to Okun, this requires a judgement on how much the poor need the extra income and how much the rich would be hurt by the extra taxes.

As a consequence, in designing an optimal tax system and in assessing the marginal costs of public funds, distortionary costs of taxation should be regarded as the price to be paid for distributional benefits in terms of reduced inequality. This trade-off between equity and efficiency of the tax system has been further analyzed by e.g. Boadway (1976), Sandmo (1998), Slemrod and Yitzaki (2001), Dahlby (2008), Kaplow (1996 and 2004), Jacobs et al. (2009) and Jacobs (2016). This literature does not assume homogeneous agents and a representative consumer, but heterogeneity in skills or preferences. Such heterogeneity is essential for justifying and understanding the benefits of redistribution.

\section{A general framework for cost-benefit analysis}

In order to link the costs of taxation and the distributional benefits of taxation to welfare and the practice of CBA, a general framework for CBA is presented (see table 2.1).

\footnotetext{
${ }^{13}$ Non-distortionary taxes are taxes that do not influence the behavior of producers and consumers. Examples are fixed levies on land per acre and to a lesser extent fixed levies per inhabitant or per dwelling. Differences and changes over time in the amount of land, the income of an inhabitant or the value of the dwelling have then little influence on the amount of tax to be paid. Fixed levies are therefore usually regressive, i.e. in case of a lower income a relatively higher percentage of income has to be paid.
} 
The top part of the framework covers the costs and benefits without any correction for MEB. The benefits (B) consist of direct and indirect effects. The latter consist of wider economic benefits, some of which pertain to the labour market (L); they show the welfare effects of behavioral changes due to the policy measure (see Atkinson and Stern, 1974) ${ }^{14}$. For example, introduction of a childcare allowance will often lead to more labour supply, in particular because mothers will seek paid work or want to work more hours ${ }^{15}$. The indirect effects or wider economic benefits are commonly included as part of the benefits B.

Table 2.1 Net benefits and the costs of taxation and the benefits of redistribution over different income groups ('income redistribution')

\begin{tabular}{lc} 
Benefits of policy measure (direct, indirect) & Mln euro's \\
Including: labour market effects of policy measure in terms of welfare & B \\
Cost of policy measure & C \\
\hline Net benefits in current Dutch CBA practice (cf Hicks-Kaldor criterion) & S = B - C \\
$\begin{array}{l}\text { Costs of taxation (due to the marginal excess burden of taxation) } \\
\text { Benefits of income redistribution by taxation }\end{array}$ & $\mathrm{F}$ \\
$\begin{array}{l}\text { Benefits of income redistribution by the policy measure } \\
\text { Net benefits according to a comprehensive measure of welfare, including the costs } \\
\text { of taxation and the benefits of redistribution }\end{array}$ & W = S - E + F + M
\end{tabular}

The cost of a policy measure (C) is the amount of resources sacrificed by the government and private stakeholders to implement the policy measure (see Romijn and Renes, 2013). For example, the public cost of building a road or bridge, or the public cost of an investment in education ${ }^{16}$.

The benefits (B) minus the costs (C) result in the balancing item 'net benefits' without any correction for MEB. This CBA-balancing item (S) is obtained by aggregating costs and benefits following the principle 1 euro is 1 euro irrespective of who gains or loses. In particular no account is taken of whether the recipient is poor or rich. This principle is also known as the Hicks-Kaldor potential compensation criterion. If these net benefits are positive, the policy measure can be interpreted as a potential Pareto-welfare improvement: the beneficiaries of the policy measure could compensate the losers and still be left with a gain. This would result in a real Pareto-welfare improvement. However, in practice those

\footnotetext{
${ }^{14}$ Also other behavioral changes due to a policy measure can be relevant and should then be incorporated, e.g. changes in saving-, schooling- and health behavior.

${ }_{15}$ This leads to a welfare gain when it helps to reduce the current distortions due to redistributive taxes, like the wage tax For an employer, the benefits of extra labour supply in terms of extra net (wage) income will mostly be compensated by a loss of leisure time. The welfare gain of extra labour supply is therefore broadly equal to the extra (wage)tax revenues for the government.

${ }^{16}$ All these costs are in terms of welfare. So, it should measure the effect on scarce public resources, like goods, capacity of production, natural resources and the quality of the environment. This implies that sometimes opportunity costs are relevant. It also implies that pure transfers or financial flows without any change in behavior are irrelevant for public costs (see Romijn and Renes, 2013, chapter 9).
} 
who lose from the policy are usually not compensated and it would be also very difficult to do so without any extra costs and without any additional behavioral changes ${ }^{17}$.

The bottom part of the framework shows the possibility of adding corrections for the cost of taxation and benefits of redistribution of income. The cost of taxation (E) refers to welfare loss caused by distortionary taxation, i.e. the marginal excess burden of taxation (MEB). In addition, two types of distributional benefits are distinguished: firstly, distributional benefits of taxation (F) and, secondly, distributional benefits of the policy measure under investigation (M).

If net benefits based on the Hicks-Kaldor criterion (S) are corrected for the costs of taxation (E) and the distributional benefits ( $\mathrm{F}$ and $\mathrm{M}$ ), this results in a CBA-balancing item based on a comprehensive welfare measure (W).

Starting from this framework, the question whether a correction should be made for the marginal excess burden of taxation can be decomposed and translated into two questions. The first question is: are the marginal distributional benefits of taxation (F) equal to the marginal distortionary effects of taxation? (E) If this is true, then no correction for the MEB is needed and the marginal cost of public funds is equal to 1 (see Jacobs et al. 2009; Jacobs, 2016). The second question is: how should the distributional effects of the policy measure for different income groups ${ }^{18}$ be accounted for? Does taking such distributional effects serious imply that the Hicks-Kaldor criterion should be abandoned and be replaced by distributional weighting of costs and benefits?

A proper response to these questions implies that different kinds of argument are taken into account: economic-theoretic, empirical, practical and political. An economic-theoretic argument is that some effects could for theoretical reasons cancel out or could only be relevant under strict theoretical conditions (see section 3). Arguing that some effects are relatively small or will be hard to quantify and translate into monetary terms reliably is an empirical argument (see section 3). The cost and time of extra analysis is more a practical argument (see sections 3 and 4). A political argument is the politicians' wish to strictly separate issues of efficiency and equity (see section 4 ).

\footnotetext{
${ }^{17}$ However, in the Netherlands when considering major policy changes, especially regarding tax policy or health care policy, policy practice is to come up with compensating measures to avoid significant losses of purchasing power for specific groups.

${ }_{18}$ Distributional benefits may also relate to other distributional effects, e.g. when different regions or population groups (e.g. smokers and non-smokers or those living nearby the new road and those not). Section 4 briefly addresses also the recording in CBA of such distributional benefits.
} 


\section{Is the marginal cost of public funds equal to one?}

\subsection{Policy measures financed by general tax revenues}

This subsection discusses whether the marginal cost of public funds is 1 , that is, whether a correction for the MEB is needed. We assume that the policy measures are financed by general national tax revenues, which is the case when there is no clear relation between a policy measure and its way of financing. In the next subsection, the implications of other ways of financing are discussed. In the discussion typically four arguments exist why no correction is needed :

1. Distributionally neutral financing;

2. Optimal taxation;

3. Consistency with the current tax system;

4. Uncertainty about the size of MEB and distributional benefits of taxes;

The merits and limitations of these arguments are summarized in table 3.1 and discussed in more detail subsequently.

Table 3.1 Arguments in favour of assuming MCPF = 1 when the policy measure is financed by general tax revenues.

\begin{tabular}{|c|c|}
\hline Argument & Explanation \\
\hline 1. Distributionally neutral financing & $\begin{array}{l}\text { In case of distributionally neutral financing, those who benefit from a policy } \\
\text { measure pay for it and those who lose are compensated for that. As a } \\
\text { consequence, distributional effects and labour market effects are absent. }\end{array}$ \\
\hline 2. Optimal taxation & $\begin{array}{l}\text { In an optimal tax system, marginal distortionary costs of taxation are equal to the } \\
\text { marginal distributional benefits of taxation. }\end{array}$ \\
\hline 3. Consistency with the current tax system & $\begin{array}{l}\text { Current tax policy reflects an implicit judgment on the distortionary cost of } \\
\text { taxation and its distributional benefits. For evaluating new policy measures, } \\
\text { consistency with this judgment implicit in the current system is a reasonable and } \\
\text { pragmatic assumption. If over time political preferences for inequality aversion } \\
\text { change drastically, first the general tax system will be revised and then for the } \\
\text { analysis of specific policy measures the assumption of MCPF }=1 \text { is again } \\
\text { reasonable. }\end{array}$ \\
\hline $\begin{array}{l}\text { 4. Uncertainty about the size of MEB and } \\
\text { distributional benefits of taxation }\end{array}$ & $\begin{array}{l}\text { Uncertainty with respect to the extent to which MCPF is larger or smaller than } 1 . \\
\text { This uncertainty refers to the assumptions used for estimating the distortionary } \\
\text { cost of taxation and the distributional benefits of taxation (e.g. how averse to } \\
\text { inequality?). }\end{array}$ \\
\hline
\end{tabular}

\section{Argument 1: Distributionally neutral financing}

According to Kaplow (1996 and 2004) the income tax can often be adjusted to offset the benefits of the public good ${ }^{19}$. In case of a uniform monetary benefit to individuals, e.g. for a

\footnotetext{
${ }^{19}$ In terms of our CBA framework, the total of $\mathrm{F}$ and $\mathrm{M}$ (the distributional benefits) are equal to zero and the costs of taxation (E) and the labour market effects $(A)$ are each equal to zero. This implies that not only $E$ and $F$, but also $M$ and $A$ can be ignored in the CBA-analysis.
} 
park or a bridge, a lump sum tax can be used. In case of benefits proportional to income or wealth, a proportional rise in the income tax can be used ${ }^{20}$. More generally, distributionally neutral financing implies that those who benefit from a policy measure should also pay for it and that those who lose should be compensated. For example, in the Netherlands, the introduction of a totally new healthcare system in 2006 was accompanied by policy measures compensating negative income effects. Kaplow proposes that cost-benefit analysis of a policy measure should be split into two steps: first an analysis of the policy measure financed distributionally neutral, and secondly an analysis of a purely redistributive adjustment to the tax system.

However, distributionally neutral financing is only possible under very strict conditions. ${ }^{21}$ These conditions will hardly ever be met for most policy measures and certainly not for policy measures financed by general tax revenues. So, the argument for distributionally neutral financing is usually not relevant for the practice of CBA.

\section{Argument 2: Optimal taxation}

In a world with distortionary taxes and redistribution, economic theory predicts that the costs of taxation are balanced against the benefits of redistribution ${ }^{22}$ (see Jacobs et al., 2009 and Jacobs, 2016). If the current tax system is optimal, then the marginal costs of general taxation are equal to the marginal benefits of reduced income inequality. In terms of our CBA-framework (see table in section 2), $\mathrm{F}$ is equal to $\mathrm{E}$ and $\mathrm{MCPF}=1$. This implies that for welfare measurement the CBA's balancing item (S) need not to be adjusted for the cost of taxation or the distributional benefits of this taxation. This conclusion depends critically on the assumption that the tax system and policy is optimal. If this is true, the theoretical conditions for $\mathrm{MCPF}=1$ to hold are not very stringent ${ }^{23}$.

The design of an optimal tax system depends critically on the aversion to inequality. A higher aversion to inequality implies larger distributional benefits and therefore also the acceptance of more distortionary taxes.

\footnotetext{
${ }^{20}$ More in general, distributional neutral financing implies that those who benefit from the policy measure should pay and that those who lose are compensated.

${ }^{21}$ The assumption is for example that the preferences of individuals for private and public goods are homogeneous and that the indirect effects of the policy measure do not influence labour supply. However, a policy measure like a child care allowance will most probably influence labour supply and this is often also the intended purpose. Also taxation or user fees should be possible on the basis of the amount of benefit from a policy measure. This implies that the government disposes of a complete set of non-linear taxes; otherwise the government cannot skim from those who benefit. But in policy practice, the government mostly levies stepwise linear taxes and lacks information about who benefits and how much. Also compensation of losers will in practice be difficult. The argument of distributional neutral financing will therefore be restricted to very general policy measures and will not apply to policy measures with regional effects or focused on specific groups. It will usually also not apply to financing by general tax revenues.

22 This theoretical model is a second best world with heterogeneous agents and imperfect information about individual earning ability or skill level, like in Mirrlees (1971). It is also assumed that distortionary taxes are levied only for distributional purposes. In a first-best world without distortionary taxes no MCPF-correction is needed. The (first best or original) Samuelson rule then applies for the optimal supply of public goods: this supply is optimal when the unweighted aggregate of the individual marginal benefits are equal to the marginal costs (Samuelson, 1954). In a second-best world with distortionary taxes, the Samuelson rule still applies provided the tax system is optimal, the preferences of all individuals are identical and the government disposes of a complete set of non-linear income taxes (Boadway and Keen, 1991).

${ }^{23}$ This applies both to linear and non-linear taxes, also when the willingness to pay for public goods changes with labour supply (non-separable preferences for private and public goods and leisure time) and even when households have heterogeneous preferences for public goods (see Jacobs, 2016).
} 
An optimal tax system assumes that sufficient information is available for a proper balancing of the distortionary costs of taxation and the distributional benefits and that this information is used in a consistent way to choose the mix of taxes and tax rates. Zoutman et al. (2016) show that the welfare weights for different income groups that are implied by the Dutch tax system $^{24}$ are in general higher for high-income groups than for lower income groups. This is what you would expect of an optimal tax system if there were general aversion to inequality. But Zoutman et al. (2016) also note some anomalies that cannot be reconciled with an optimal tax system. In particular in the lower part of the income distribution the welfare weights rise with income instead of fall. This conclusion for the Dutch tax system is in line with the relatively low social welfare weights for the working poor found in studies on the tax system in other countries (see e.g. Bourguignon and Spadaro (2012) and Bargain et al. $(2014) \cdot{ }^{25}$

Optimal tax policy assumes that redistribution by the government is efficient given a certain degree of aversion against inequality. In the Netherlands many different types of policy measures are used for redistributive purposes, e.g. progressive income tax, minimum wage, housing subsidies and tax deduction for interest from mortgages. For many reasons (e.g. political strategic reasons or information problems about the policy measures' efficiency for redistribution) this current mix may not be optimal and efficient for any specification of aversion against inequality.

These arguments about the optimality of the tax system and tax policy in practice, imply that the assumption of optimal taxation is probably too strong and therefore cannot be used for justifying $\mathrm{MCPF}=1$.

\section{Argument 3: Consistency with the current tax system}

A substantially weaker assumption than optimal taxation is consistency with the current tax system. The current tax system ${ }^{26}$ can be assumed to be broadly consistent with the current political and societal preferences. This tax system will roughly reflect the preferences and decision-making power of the successive governments and their constituents. The resulting tax system ${ }^{27}$ is a specific combination of distortionary taxes and distributional benefits. Financing public expenditure with less distortionary taxes would also have been possible,

\footnotetext{
${ }^{24}$ This assumes that redistribution by the government is efficient.

${ }^{25}$ The insights from political economy, like the role of the median voter and lobby groups in public decision-making, can provide an explanation for such clear deviations from the optimal tax system. But optimal tax theory may also be combined in one model with key-assumptions from political economy, see e.g. Acemoglu and Golosov (2010).

${ }^{26}$ Together with often closely related transfers by the government to households. So, the assumption of optimal tax policy is about the tax and social security system as a whole.

${ }^{27}$ This argument has also been applied to analyzing long term trends in public expenditure in the USA, UK, France, Germany and Italy (see Florio and Colautti, 2005). Over time the benefits of extra public expenditure are balanced by politicians and society against the distortionary costs of extra taxes. According to Wagner's law the ratio between public expenditures and national income will grow exponentially, as higher income results in higher demand for public goods and transfers. But according to Pigou this requires rising taxation and leads to rising distortionary costs of these extra taxes; this will constrain the growth of public expenditure. The exponential growth of public expenditure according to Wagner's law and Pigou's conjecture about rising marginal excess burdens of taxation provides a logistic growth theory of public expenditures: first a slow increase, then an exponential increase and later a stabilization of public expenditure as a percentage of national income. This may also provide an explanation for the growth of public expenditure in the Netherlands from 14\% GDP in 1850 to more than 60\% GDP in 1983 (see Bos, 2006). However, in some decades Dutch public expenditure has dropped to $43 \%$ GDP in 2017. This clearly does not fit in this logistic growth theory. It could perhaps be explained as a change in Dutch societal preferences for inequality (towards lower preference for inequality and a more limited role of the government) and which may partly be caused by more information about the distortionary costs of taxation and social security, e.g. in terms of rising unemployment and public debt.
} 
but apparently the distributional benefits of the actual choice of distortionary taxes provide sufficient compensation for the welfare loss due to these distortions. A correction for the MEB is then not necessary. CBA's can then proceed using MCPF $=1$ resulting in CBAoutcomes that are consistent with the preferences for (in)equality as laid down in the current tax(-benefit) system and with other government policy.

Assuming consistency with the current tax system and hence using MCPF = 1 in CBA's is also the only politically neutral choice. Any alternative assumption (MCPF $>1$ of MCPF $<1$ ) implies that the CBA-analyst regards the current tax system as insufficiently redistributional $(\mathrm{MCPF}<1)$ or as too redistributional $(\mathrm{MCPF}>1)$, which can be regarded as a political statement.

Although it is reasonable to assume that the current tax system reflects current political preferences on the trade-off between equity and efficiency, such political preferences may change over time. Furthermore, political parties in the opposition or other groups outside the government may have a substantially different aversion against inequality. These arguments might suggest that with a forward looking view or from the perspective of groups outside the government, the assumption that MCPF $=1$ for CBA's of specific policy measures could well be arbitrary and misleading. However, such suggestion is invalid, as becomes clear by applying a two-step argument. Suppose in the near future people with substantially different inequality aversion will come to power. Then they should first adjust the general tax system in line with their substantially different inequality aversion. In a second stage, specific policy measures can be evaluated on the basis of their costs and benefits and then again the reasonable assumption can be made that for marginal changes the distortionary cost of taxation is equal to the distributional benefits of these taxes. As a consequence, whether the specific policy measure will be evaluated in view of the current or future tax system will not matter for its outcome.

\section{Argument 4: Uncertainty about the size of the MEB and the distributional benefits}

Estimates of the size of the MEB of the current tax system vary substantially (see text box below) and depend critically on the assumptions used. The distributional benefits of the tax system depend on the degree of inequality aversion and the specific method used (see Pol, Bos and Romijn, 2017). For some assumptions and methods, the MEB and the distributional benefits are of approximately equal size, but with other assumptions the MCPF can be larger or smaller than one. This occurs particularly if the degree of inequality aversion is chosen in such a way that the current tax system does not come close to the degree of redistribution that is considered optimal for the chosen degree of inequality aversion. Such a choice for the inequality aversion implies that the current tax system does not reflect and is not consistent with current preferences.

However, the empirical evidence does not force one to choose such an inconsistent set of assumptions. The empirical evidence allows one to choose a consistent set of assumptions in which MCPF $=1$. Therefore, empirical evidence does not help much when it comes to the size of the MCPF. We are essentially left with the earlier argument about consistency. 


\section{Uncertainty about the size of the MEB}

The European CBA-guidelines on transport infrastructure (Bickel et al., 2006) recommend not to make a correction for the marginal excess burden of taxation (MEB) because of the uncertainty in the estimates. For example, Kleven and Kreiner (2003) illustrate for OECD-countries that the size of the MEB depends on the way of financing (higher average tax rate or more progressive taxes), the inclusion of the participation decision and whether also non-labour income revenues are taken into account, like allowances and social benefits. Also for the Netherlands, estimates of the MEB can differ substantially depending on the assumptions used (see Jacobs, 2015).

\begin{tabular}{|c|c|c|c|c|}
\hline & $\begin{array}{r}\text { Compensated } \\
\text { labour supply } \\
\text { elasticity }\end{array}$ & $\begin{array}{r}\text { Elasticity of } \\
\text { demand for } \\
\text { labour }\end{array}$ & $\begin{array}{r}\text { Marginal rate } \\
\text { income tax } \\
\text { and social } \\
\text { security } \\
\text { contributions }\end{array}$ & $\begin{array}{r}\text { Marginal } \\
\text { excess } \\
\text { burden }\end{array}$ \\
\hline $\begin{array}{l}\text { Standardmodel and } \\
\text { assumptions }\end{array}$ & 0.3 & infinite & 0.56 & 0.38 \\
\hline \multicolumn{5}{|l|}{ Three alternative assumptions } \\
\hline \multicolumn{5}{|l|}{$\begin{array}{l}\text { 1. Different labour supply } \\
\text { elasticity }\end{array}$} \\
\hline a. low & 0.2 & infinite & 0.56 & 0.25 \\
\hline b. high & 0.4 & infinite & 0.56 & 0.51 \\
\hline $\begin{array}{l}\text { 2. Including also distortions by } \\
\text { employers' social security } \\
\text { contributions }\end{array}$ & 0.3 & 2.5 & 0.80 & 1.07 \\
\hline
\end{tabular}

According to Jacobs (2015) the MEB of general tax and social security revenues in the Netherlands is about 0.50 , i.e. a tax burden of 50 eurocent per extra euro of public expenditure. Some very reasonable alternative assumption can lead to substantially different estimates. For example, in the standard model the MEB is 0.38 , but if labour supply elasticity is lower or higher the MEB changes from 0.25 to 0.51 . If also the distortionary effects of employers' social security contributions are taken into account the estimate of Dutch the MEB more than doubles (1.07).

According to Mishan and Quah (2007, see in particular footnote 1 on p. 24, appendix 4 and 13), including a correction for the marginal excess burden of taxation is a common mistake in many CBA-textbooks. Their argument is not only that the estimate of MEB is uncertain, but also that it will in general be very small. Mishan and Quah argue that in the real world there will be many different types of deviations from a perfectly competitive economy, e.g. due to monopolies, information problems, transaction costs, efficiency wages, regulations, taxes, subsidies and external effects. In such a world, the net effect of a specific policy measure on overall distortions can be either positive or negative. As it concerns a policy measure of marginal importance to the whole economy, it will not have any significant effect on the distortions in the economy. The measurement of the net effect on welfare will be illusory and should therefore best be ignored 28 .

\footnotetext{
${ }^{28}$ In a separate appendix, the distortionary effect of an income tax is presented as a case in point. For example, it is stressed that fixed factor quantities like the number of hours work are generally the rule and not the exception in modern economies (Mishan and Quah, 2007, appendix 13). As a consequence, the trade-off between labour and leisure will be substantially distorted and will remain so after a marginal increase in the income tax rates.
} 
Our conclusion is therefore that the argument of consistency with the current tax system (argument 3) offers convincing ground for assuming MCPF is equal to one. The argument of uncertainty of the estimates of MEB and distributional benefits (argument 4) is less convincing, but makes clear that empirical evidence does not help much in assessing the value of MCPF. The two other arguments, about distributionally neutral financing and optimal taxation, are purely theoretic arguments and do not help much in settling the debate on the best solution for CBA practice.

\subsection{Alternative sources of financing}

Policy measures can be financed from other sources than general tax revenues. Examples are toll fees and congestion charges, social security contributions, public-private partnerships, local taxes, loans ${ }^{29}$ or a mix of financing by central and local government. Would our analysis about MCPF = 1 then still apply?

\section{Choosing an alternative source of financing is a separate policy measure}

All these other types of financing should be regarded as a separate policy measure that should be analysed separately in a CBA. It would be an analysis similar to a change in a specific tax or a general revision of the tax system. For all such policy measures, the financing issue of the policy measure can best be ignored. As a consequence, the question whether MCPF = 1 is not relevant, only measuring the costs and benefits, including the distortionary effects of the policy measure as such (L) and the distributional benefits of the policy measure $(\mathrm{M})$.

Different policy measures may have positive and negative synergies. An example is the construction of a new road financed by (an increase in) a congestion charge. This case should be analysed by a CBA of the construction of the new road financed by general tax and a separate CBA of the introduction of a congestion charge. Finally, both measures can be combined in a joint CBA. Financing a road via a congestion charge may also be compared in a CBA with various other ways of financing, e.g. (an increase in) car registration tax, (an increase in) excise duty on petrol or a public-private partnership. In each of these cases the financing measure is a separate issue and should be analysed separately, while taking into account their distortionary cost and their distributional benefits.

\footnotetext{
${ }^{29}$ If the policy measure is financed via a loan, this may also have distortionary effects, e.g. when the repayment of the loan is financed via postponed general tax revenues or by crowding out the financing of private investments. So, financing public expenditure via a loan instead of a tax is generally not a free lunch, but may have less distortionary effects than financing via general tax revenues.
} 


\section{Distributional benefits of the policy measure}

Nearly a century ago, Pigou emphasized the general principle that for optimal public expenditure the social gain from a marginal increase in resource use should be the same everywhere. This principle ensures not only an efficient balance between resource use in public and private sectors (see sections 2 and 3), but also between resources used in different parts of the public sector. He illustrates the latter with the following example:

"Expenditure should be distributed between battleships and Poor Relief in such wise that the last shilling devoted to each of them yields the same return of satisfaction" (see Pigou, 1928 and Sandmo, 2011, p. 261).

This quote indicates that distributional benefits of a policy measure should certainly not be ignored in a CBA.

However, the net benefits in a CBA following the Hicks-Kaldor criterion (S), give an equal weight to the effects of a policy measure for low and high incomes (1 euro is 1 euro irrespective of who gains or loses, see section 2). As a consequence, distributional benefits (or costs) from a transfer from high income to low income (or vice versa) are ignored. A choice for MCPF $=1$ implies that the distributional benefits of taxation are included.

Consistency then suggests that also the distributional effects of the policy measure should be accounted for.

Two solutions are possible to remedy this. The first is to quantify the effects on various income groups and show these effects separately from the CBA's balancing item, e.g. to present them as a P.M. item. This would be on a par with the treatment in CBA's of any other effects, e.g. effects on biodiversity, that are mentioned but not translated into monetary (welfare) terms and therefore are excluded from the CBA's net benefits. The second solution is to incorporate the distributional benefits in the CBA's net benefits by using distributional weighting, i.e. to give a higher weight to benefits for low income groups than for high income groups. In this way the distributional benefits (M) are included in the CBA's balancing item, possibly as a correction to net benefits following the Hicks-Kaldor criterion (see e.g. Harberger, 1978, Mishan and Quah, 2007, Florio, 2014, Bargain et al., 2013, Hendren, 2014 and Zoutman et al. 2016).

The first solution requires data and models that allow the calculation of effects for different income groups. These are in principle available or could be developed, but require a lot of additional analysis. The second solution requires taking another step which primarily involves establishing a set of weights for different income groups. Pol, Bos and Romijn (2017) show that various methods are possible and that for each method also various more operational choices are to be made. 
Table 4.1 Should benefits of redistribution over income groups be included in the CBA's balancing item?

\begin{tabular}{|c|c|c|}
\hline & Yes & No \\
\hline Informative? & $\begin{array}{l}\text { Benefits of redistribution of income are } \\
\text { important for a broad concept of } \\
\text { welfare. Incorporating this in the CBA's } \\
\text { balancing item, would immediately show } \\
\text { the importance of the income } \\
\text { redistribution in comparison to the other } \\
\text { costs and benefits of the policy } \\
\text { measure. }\end{array}$ & $\begin{array}{l}\text { - CBA should show all major effects, but not all effects } \\
\text { should be put in monetary terms and be included in } \\
\text { CBA's balancing item. When relevant the effects for } \\
\text { various groups of income could be shown. } \\
\text { - This would stress the importance of income } \\
\text { redistribution too much in comparison to other } \\
\text { aspects that are also not reflected in CBA's net } \\
\text { balancing item, e.g. environmental issues and other } \\
\text { distributional issues. } \\
\text { - This would make CBA even more complex and } \\
\text { inaccessible for many users. } \\
\text { - This would still not show the income effect on } \\
\text { different types of households, workers and non- } \\
\text { workers and other differences within income groups. }\end{array}$ \\
\hline $\begin{array}{l}\text { Sufficiently reliable, } \\
\text { comparable and } \\
\text { objective? }\end{array}$ & $\begin{array}{l}\text { Many different weighting schemes are } \\
\text { possible, but by choosing an empirical } \\
\text { method, national guidelines and a } \\
\text { standard sensitivity analysis, the major } \\
\text { problems in terms of reliability, } \\
\text { comparability and objectivity can be } \\
\text { resolved. It should then be preferred to } \\
\text { the arbitrary and not politically neutral } \\
\text { balancing item cf Hicks-Kaldor, i.e. an } \\
\text { unweighted aggregate of net benefits for } \\
\text { different income groups. }\end{array}$ & $\begin{array}{l}\text { Guidelines for a specific empirical method do not } \\
\text { sufficiently resolve the problems of reliability, } \\
\text { comparability and objective. The method and } \\
\text { assumptions used will still be arbitrary and not } \\
\text { sufficiently reliable. The net effect would be that policy } \\
\text { makers would discuss more the weighting scheme } \\
\text { instead of the results of the CBA. }\end{array}$ \\
\hline $\begin{array}{l}\text { No serious conflict with } \\
\text { division of task with } \\
\text { politics? }\end{array}$ & $\begin{array}{l}\text { A CBA should inform policy makers in a } \\
\text { balanced way by stressing that the } \\
\text { Hicks-Kaldor criterion is not politically } \\
\text { neutral and by showing the implications } \\
\text { of alternative weighting schemes. }\end{array}$ & $\begin{array}{l}\text { A CBA should inform policy makers but should refrain } \\
\text { from taking over the role of the politician. The Hicks- } \\
\text { Kaldor criterion is not politically neutral but } \\
\text { nevertheless a useful benchmark for political debate, in } \\
\text { particular when also major effects for various groups of } \\
\text { income are shown. }\end{array}$ \\
\hline
\end{tabular}

In the Dutch CBA-working group on the MCPF, the merits and limitations of distributional weighting were extensively discussed (see table 4.1). The conclusion was that -though the Hicks-Kaldor criterion is not politically neutral- it is nevertheless a useful benchmark for political debate, in particular when also major effects for various groups of income are shown when relevant. The more ambitious solution of incorporating distributional benefits in the CBA by also adjusting the CBA's balancing item using distributional weighting was rejected. This was considered to have major adverse effects on the use of CBA in general in Dutch political decision-making.

This conclusion is in line with international CBA practice. In international CBA-practice welfare weights, i.e. different weights for different income groups, is hardly applied. This is even true when their CBA guidelines recommend it. Major cases in point are CBA at the Worldbank and in the UK. Since the seventies, CBA's are a major trade mark of the Worldbank. According to the old CBA Guidelines of the Worldbank (Little and Mirrlees, 1974) benefits for households in CBA should take account of their income, in particular when a policy measure is aimed at improving the situation of the poor. However, in the Worldbank's CBA practice (see Worldbank, 2010 and Riet, 2016) this was hardly ever done. One reason is that it would have made CBA for projects in development countries even more 
difficult. A second reason is that CBA's were often not relevant for financing a project. A third reason is that CBA's were mostly used for sectors in which redistribution of income was considered to be a secondary issue, e.g. for agriculture, energy, transport and water. For policy measures with respect to education, healthcare and the environment, hardly ever a CBA was made.

The CBA-guidelines of the UK-Ministry of finance ('UK Green Book', HM Treasury, 2003) support the idea that in assessing cost and benefits also the income and wealth of households that gain or lose should be taken into account. However, it is also remarked that compiling information on this would often lead to disproportionally extra costs. Furthermore, no explanation is given for what type of policy measures or under what kind of circumstances providing such additional information is needed. 


\section{Conclusions}

According to economic theory, taxation drives a wedge between private and public benefits, which distorts labour supply, consumption and investment and leads to loss of welfare. One would therefore expect that in cost-benefit analysis (CBA) of public expenditure a correction is made for the costs of taxation, i.e. for the marginal excess burden of taxation (MEB). However, looking at CBA practice all over the world, textbooks on CBA, various specific CBA guidelines and economic literature, no consensus exists about such a correction. In most countries in the world no correction for the MEB is made, in many CBA guidelines the issue is not even mentioned, while CBA textbooks and economic literature disagree on the need for a correction.

This paper provides for the first time an overview of the theoretical, empirical and practical arguments in favor or against a MEB correction. It argues that the best approach for CBA's is to assume that the MEB is broadly counterbalanced by the benefits of redistribution of these taxes. This assumption is consistent with the preferences for equality in a country's current tax system and is a simple, pragmatic and politically neutral assumption. This assumption does not imply that the tax system is optimal or that CBA's should be distributionally weighted. As a consequence, the preferred approach is to assume in general that marginal cost of public funds is equal to one and then no correction is needed in CBAs for the MEB.

A policy measure may also be financed by an alternative source of financing than general tax revenues, like a road financed via congestion charges or by higher excise duties on petrol. These alternative ways of financing should be regarded as separate policy measures that should be analysed and compared separately in a CBA; this comparison includes also their distortionary costs and their distributional benefits. 


\section{References}

Acemoglu, D. en M. Golosov, 2010, Dynamic Mirrlees taxation under political economy constraints, Review of Economic Studies, vol. 77: 841-881.

Asian Development Bank, 2013, Cost-benefit analysis for development; a practical guide.

Atkinson, A. B. en Stern, N. H., 1974, Pigou, taxation and public goods, Review of Economic Studies, vol. 41: 119-128.

Barrios, S., J. Pycroft en B. Saveyn, 2013, The marginal cost of public funds in the EU: the case of labour versus green taxes, Publications Office of the European Union, Luxembourg.

Bickel, P.R., A. Friedrich, A. Burgess en P. Fagiani, 2006, Proposal for harmonised guidelines, HEATCO (Developing Harmonised European Approaches for Transport Costing and Project Assessment, 2006, Proposal for Harmonised Guidelines.

Boadway, R., 1976, Integrating equity and efficiency in applied welfare economics, The Quarterly Journal of Economics, vol. 90(4): 541-556.

Boadway, R. en M. Keen, 1993, Public goods, self-selection and optimal income taxation, International Economic Review, vol. 34: 463-478.

Boardman, A.E., D.H. Greenberg, A.R. Vining en D.L. Weimer, 2006, Cost-Benefit Analysis: Concepts and practice, 3rd edition, Pearson, Upper Saddle River.

Bos, F., 2006, Nederlandse collectieve uitgaven in historisch perspectief, CPB Document.

Bos, F., 2008, The Dutch Fiscal Framework; History, Current Practice and the Role of the CPB, OECD Journal on Budgeting, vol. 8, no. 1, 7-48.

Bos, F. and C. Teulings, 2012, The World's Oldest Fiscal Watchdog: CPB's Analyses Foster Consensus on Economic Policy, CPB Discussion Paper 2007.

Bos, F. and C. Teulings, 2013, Short and Long-term Forecasting by the Netherlands Bureau for Economic Policy Analysis (CPB): Science, Witchcraft or Practical Tool for Policy?, OECD Journal of Budgeting, Volume 13/1, pp. 45-56.

Bos, F. and P. Zwaneveld, 2017, Cost-benefit analysis for flood-risk management and water governance in the Netherlands; an overview of one century, CPB Background paper.

Burgess, D.F. and R. Zerbe, 2011, Appropriate discounting for benefit-cost analysis, Journal of Benefit-Cost analysis, 2, pp. 1-20.

Burgess, D.F., 2013, Reconciling Alternative Views About the Appropriate Social Discount Rate, Journal of Public Economics, Vol. 97, pp. 9-17. 
Dahlby, B. 2008, The marginal cost of public funds: Theory and applications, MIT Press, Cambridge.

European Commission, 2014, Guide to Cost-Benefit Analysis of Investment Project; economic appraisal tool for Cohesion Policy 2014-2020.

Feldstein, M.S., 1997, How Big Should Government Be?,National Tax Journal 50 No. 2: 197213

Florio, M., 2014, Applied welfare economics: Cost-Benefit Analysis of projects and policies, Routledge, New York.

Florio, M. and S. Colautti, 2005, A logistic growth theory of public expenditures: a study of five countries over 100 years, Public Choice, vol. 122, 355-393.

Harberger, A.C., 1978, On the use of distributional weights in Social Cost-Benefit Analysis, Journal of Political Economy, vol. 86(2): S87-S120.

Harberger, A.C., 2007, Suggested new steps towards the practical implementation of costbenefit analysis, working paper

Heckman, J.J., S.H. Moon, R. Pinto, P.A. Savelyev and A. Yavitz, 2010, The rate of return to the HighScope Perry Preschool Program, Journal of Public Economics 94, 114-128.

Hendren, N., 2014, The inequality deflator: interpersonal comparisons without a social welfare function, NBER Working Paper 20351.

Jacobs, B., 2009, The marginal cost of public funds and optimal second-best policy rules, mimeo: Erasmus Universiteit Rotterdam.

Jacobs, B. 2015, De prijs van gelijkheid, Prometheus, Amsterdam.

Jacobs, B., 2018, The marginal cost of public funds is one at the optimal tax system, International Tax and Public Finance, published online: 16 January 2018.

Jacobs, B., R. de Mooij en A. Armstrong, 2009, De prijs van de overheid, CPB, Den Haag.

Jacobs, B. and R. de Mooij, 2009a, De marginale kosten van publieke fondsen zijn gelijk aan één, ESB 94, pp. 532-535.

Jacobs, B. and R. de Mooij, 2009b, Naschrift op: De marginale kosten van publieke fondsen zijn gelijk aan één, ESB 94 p. 669.

Kaplow, L., 1996, The optimal supply of public goods and the distortionary cost of taxation. National Tax Journal, vol. 49(4): 513-533.

Kaplow, L., 2004, On the (ir)relevance of distribution and labor supply distortion to public goods provision and regulation, Journal of Economic Perspectives, vol. 18: 159-175. 
Kleven, H.J. en C.T. Kreiner, 2003, The marginal cost of public funds in OECD countries: Hours of work versus labor force participation, CESIFO Working Paper 935.

Koopmans, C. and M. de Nooij, 2009, Reactie op: De marginale kosten van publieke fondsen zijn gelijk aan één, ESB 94, pp. 605;

Mirrlees, J.A., 1971, An exploration in the theory of optimum income taxation, Review of Economic Studies, vol. 38: 175-208.

Mishan, E.J. en E. Quah, 2007, Cost-benefit analysis, 5th Edition, Routledge, New York.

OECD, 2006, Cost-benefit analysis and the environment; recent developments.

Okun, A., 1975, Equality and Efficiency: the Big Trade-off, Brookings Institution Press, Reprint 2015.

OMB (US Office of Management and Budget), 1992, Circular A-94: Guidelines and Discount Rates for Benefit-Cost Analysis of Federal Programs, Washington, DC.

Pigou, A.C., 1920, The economics of welfare, $4^{\text {th }}$ ed. London, MacMilan, 1952

Pigou, A.C., 1928, A study in public finance, 3d ed, London, Macmillan, 1947.

Pol, van der, T., F. Bos and G. Romijn, 2017, Distributionally Weighted Cost-Benefit Analysis: From Theory to Practice, CPB Discussion Paper; an earlier draft was presented at the $9^{\text {th }}$ Conference of the Society for Benefit-Cost Analysis, March 15-17 2017, Washington DC.

Romijn, G., \& Renes, G. , 2013, General Guidance for Cost-Benefit Analysis. The Hague. CPB / PBL, The Hague. https://www.cpb.nl/sites/default/files/publicaties/download/cbaguidance.pdf

Samuelson, P. A., 1954, The pure theory of public expenditure, Review of Economics and Statistics, vol. 36: 387-389.

Sandmo, A., 1998, Redistribution and the marginal cost of public funds, Journal of Public Economics, vol. 70, 365-382.

Sandmo, A., 2011, Economics evolving; a history of economic thought, Princeton University Press.

Slemrod, J. and Yitzhaki, S., 2001, Integrating expenditure and tax decisions: the marginal cost of funds and the marginal benefit of projects, National Tax Journal, 54 no. 2, 189-202.

Treasury, H.M. 2011, The Green Book: Appraisal and evaluation in central government treasury guidance, TSO, London.

Werkgroep Kosten van belastingheffing en MKBA's, 2017, Kosten van Belastingheffing, Baten van Inkomensherverdeling en MKBA's, Report to the Dutch government. 
World Bank, 1994, Operational Manual OP 10.04 Economic evaluation of investment operations.

World Bank, 2010, Cost-benefit analysis in World Bank projects.

Zerbe, R., T.B. Davis, N. Garland and T. Scott, 2010, Towards principles and standards in the use of benefit-cost analysis; a summary of work, report by the Benefit-Cost Analysis Center.

Zoutman, F.T., B. Jacobs and E.L.W. Jongen, 2016, Redistributive politics and the tyranny of the middle class, T. Institute, TI 2016-032/VI. 

Publisher:

CPB Netherlands Bureau for Economic Policy Analysis

P.O. Box $80510 \mid 2508$ GM The Hague

$\mathrm{T}$ (088) 9846000

January 2018 